\title{
POLISH SCHOOL OF THE LITERATURE OF FACT: CHARACTERS OF THE REPORTAGES AS THE REFLECTION OF REALITY Khrystyna Golovko
}

\begin{abstract}
The article analyzes the key feature of Polish school of the literature of fact, specifically the journalistic work with the heroes of the materials that are the basis of the reportorial text. Peculiarities of characters typical for Polish reportage are analyzed. Further, the article explores the specific features of communicative strategies of Polish reporters, reportorial technique. For a better understanding the visual examples from reportorial text are provided.
\end{abstract}

Keywords: New Journalism, Polish literature of fact, communicative strategy, "live-in" method.

Literary journalism or «New Journalism», originated in the United States of America in the 1960 s of the twentieth century at the time of industrial, socio-political changes, quickly gained popularity among readers, acquired new forms and varieties spreading beyond the country. One of the most popular schools of literary journalism is Polish school of the «literature of fact», which evolved separately from English-American tendency.

It is important to outline that the Polish Literary criticism regards the 20th years of the 20th century as the birth of reportage. The emergence of reportage was influenced by the rapid development of the Polish press. Literary critics consider the Nobel prize winners Henryk Sienkiewicz and Wladyslaw Reymont as the first Polish reporters, and "The Pilgrimage to the Mountain of Light" by Reymont (1895) - as the first reportage [Baley L., 2012].

In 1924 the first attempts of reportage appeared in the literary-social weekly «WiadomościLiterackie». Melchior Wankowicz, the wandering reporter Arkady Fiedler (the most outstanding work "Canada smelling of tar" and the journalist of "hotspots" Ksawery Pruszynski belong to the reporters, who began their work before the World War II. The latter one is considered to be one of the most important creators of the prewar reportage. Since then, the Polish reportage has formed its own tradition and development, the 
groups of reporters are organized around such popular editions, as «Polityka», «Literatura», «Swiat», "GazetaWyborcza».

According to Polish Dictionary of Literary Genres», the reportage is a "genre on the edge» of opinion-based journalism, nonfiction and fiction. It was formed in the second half of the nineteenth century. The main attribute of this time frame was the dynamic development of the press. The works of this period are a historical description of the events the author witnessed himself»[Bernacki M., Pawlus M.,1999].

One of the key aspects of this school is the thing that reporters, due to the genre of literary reportage, could narrate common human stories that described true, everyday life. "We showed the facts of life, the way people lived, worked, the healthcare they got, the way they travelled to work. These details - dressed in good language and form - made readers draw conclusions»[Bartosz M.,2010].

Reporters found unique, illustrative and metaphorical heroes, whose story reflected the time, problems and situations. It is important to emphasize that Polish reporters described unbiassed reality based on facts. Therefore, the characters in Polish reportage play the role of prototypes whose life reflect the reality. They explain the situation to a reader in a better way, allow you to feel the kinship, the proximity of the situation. "The character is the most sacred thing for a reporter and a journalist. He/she gives his/her life into your hands and you are responsible for this life. You should think about the characters even more than theythemselves»[Shcheglova J., 2012].

\section{The characters of Polish reportage}

Polish literary reportage puts the story of a man (people) as the core of the text. The well-known Polish reporter Witold Szablowski says: «People are always in the center of the reportage for me. And the events are not some kind of abstraction hanging in the air, they are also created by people. The events always mean people, their emotions, courage, ideas, principles»[Kostovskaya A., 2016].

Any person,whose real-life situation reflects an event, phenomenon, tendency in the deepest, most vivid way, can be the hero of a reportage. Most often journalists prefer to choose ordinary people with unusual stories to be the heroes of a reportage in order to make reporting close to a reader. A journalist must find the very exclusive heroes who will undoubtedly play one of the most important roles in the reporting. They should be real, bold, documentary characters who «speak» in the text with their voices and notwith a «voice» of the author, with their habits, defects, temper, with precise detail. After all, media researcher Victoriia Babenko confirms that «There is no such sphere (socium, science, economics, politics) that can not be revealed through the certain fates, personaliteis, characters» [Babenko V., 2013, p. 268].

Mostly, the characters are attached to the themes, problems and specialization of a reporter, which allows a reporter to study the specific topic that interests him/her in detail. Polish reporters, focusing on specific issues or regions, often become wellknown experts: Wojciech Jagielski - expert on Africa, Pawel Smolenski - on Israel and Palestine, Mariusz Szczygiel- on the Czech Republic, Jacek Hugo-Bader and Krystyna Kurczab-Redlich- on Russia, Wojciech Tochman as well as Pawel Reszka-onthe Near East and military conflicts, Piotr Ibrahim Kalwas - an expert on Egypt, Ziemowit Szczerek, Piotr Andrusieczko, Katarzyna Kwiatkowska-Moskalewiczwrite about Ukraine etc.

For example, Jacek Hugo-Bader in his book «White Fever :a journey to the frozen heart of Siberia», line by line narrates about the lives of representatives of the underclass: homeless, alcoholics, drug addicts, trying to feel and understand their life as it stands. After all, the reporter is convincedthat such stories help to understand the global nature of the phenomena. «I write about poverty, about the homeless. I think that, in general, there is no difference. The world of exiles, criminals, prostitutes, drug addicts, alcoholics ... in these countries does not differ very much»[Baley L., 2012]. 
More rarely, reporters write about politicians or the intellectuals of any sphere, since their life is at a certain distance. The choice of heroes depends on the type of a reportage. The political literary reportage, by contrast, savors spicy bits of scandal from the life of prominent politicians and looks for the most interesting features in these characters in order to open their unknown sides to the reader. The apt reportage by Pawel Reszkaabout Donald Tusk, former Polish Prime Minister, is worth mentioning here. Without regard to politician's media company and his «plastic image» Reszka managed to show a real Tusk during a football match with his subordinates and two former national football players, who were allowed to pass a ball, but did not have the right to hit it, only Tusk's assistant was allowed to score the goals. However, when the reporters came back to see the game three days later, they were identified and in the field there was established an idyllic picture, which Tusk and his team promoted in the electoral campaign, and, according to Reszka, that was the thing that was needed for the reportage in order to show a true story of the politician. "There are two pictures, needed for reportage: real Tusk and the illusion that he creates for the media. It was a shock and since then Tusk has refused to speak with me»[Kovalenko O., Golovko K.,2014].

Instead, a social reportage tends to be a story about usual people with unusual stories. Polish reporter, the author of the "Gotland», "Make Your Own Paradise», Mariusz Szczygiel, one of the journalists of young generation of Polish «literature of fact», grouping around «Gazeta Wyborcza» (Electoral Newspaper) («Krystyna Kurczab-Redlich, Jacek Hugo-Bader, Mariusz Szczygiel, Wojciech Tochman,PawelSmolenski,Krzysztof Varga also belong to this generation» [Baley L., 2012]) in his reports always focuses on human being: «In the reportage, above all, a person is the most important thingfor us. Many other genres, even fiction, describe a person, but in the reportage we try to understand a person. Do not dig, do not search for all the personal details that he or she may want to keep, but simply understand»[Knyazevich 0., 2011].

To understand people and to tell the world their story, in which the world will see the reflection of the reality created and organized by human being, and how reality itself becomes a person, since human fate is the best illustration of the things happening around. Polish reportage school is characterized by the use of several characters in the text with accents on several major stories. Usually reporters, sort of, involve the heroes in the text: journalists give a direct speech through dialogues, break the text design, add and remove characters from the material. "There should be several characters in the text. The best variant is $5-6$, if only, you do not write material about one person. You always have to set the aim to find the right heroes»[Shcheglova J.,2012].

To make the picture look comprehensive, journalists combine characters with either a common problem or idea. Sometimes they unite such characters not only in one reportage or section, but also publish books with stories, creating in this way the continuity of one great story, which in its turn consists of small stories of many people. It is important to emphasize that sometimes it is not a specific person who becomes the main character, but the whole institution, system, community or phenomenon described in the literary reportage. For example, in the already cited book «White Fever:a journey to the frozen heart of Siberia» by Jacek Hugo-Bader the central reportage of the book is a story that describes the fate of theEvenks reindeer-breeders brigade and its main enemy, which destroyed it entirely - a white fever. Sometimes reporters themselves become the heroes of their materials, as in the "forest of things» byRyszard Kapuscinski, or a vivid example of extremely popular reportage, where the journalists become the heroes. The experiment of the spouses of reporters Izabela Meyza and Witold Szablowski, who wrote a book of reportages about the Polish People's Republic«Nasz maly PRL» («Our Little Polish People's Republic») which evoked life of the Poles in the 80-s of the twentieth century. Researcher N. Maletich calls it «reportage-transormation»[Maletich N., 2013].

The couple did not use the modern technical communication tools in order to compare the way the modern Poles differ from the ones from those times. «We dressed as 
people in the days of the Polish People's Republic. Witold took a jacket, which hadn't been worn for a long time, from a village, and I made a perm. People often took us as for the homeless. One day our neighbor even brought us some clothes for a child. He did not know that we were engaged in that project» recalls the reporter [Abis T., 2013].

It is important to emphasize that sometimes the dead are also characters, this reportage technique is illustrated the best by the phenomenal reportage of Wojciech Tochman "Like eating a stone», where the journalist talks about the crippled fates of people caused by the war in Bosnia and Herzegovina in 1992-1995, looking through alive witnesses into the stories of those who died. «I do not write about the graves. I'm talking about alive people who are standing above the smelly holes in the earth. About the things they carry within themselves, it is important to me» [Book Institute Poland].

One of the main genre canons of Polish literary reportage is understanding a person. It is reminded by one of the most well-known Polish reporters Witold Szablowski: " A perfect story, no matter what country it is written in, should be close to people as much as possible. There is nothing simpler than to make a reportage about a famous politician or a pop star. It is easy to write about them, but they are not the ones who live prototype life of the country. Reportage should represent the pulse of the country it is written in. One should feel vodka, drunk together, shared food, cigarettes,smoked together,the time, spent together, in it» [Baley L.,2013].

And in order to describe the life of these people, first of all, you must be one of them. It was emphasized by Yves Agnes, a leading representative of French school of reportage, the editor of the "LeMonde» newspaper, «You usually have to let themaccept you or even to make them forget about you »...". Bringing this behavior to the maximum means «immersion» [Agnes Y., 2013, P.308]. A reporter sometimes becomes a friend, brother, and like-minded fellow for heroes, and to make things work the journalist needs some preparation and specific professional skills that will help him/her to «tell» the story.

\section{A communicative strategy of working with heroes in Polish reportage}

In Polish literature of fact it is the work with the heroes that is an outstanding feature, since the stories, found by reporters, illustrate not only life of a particular person, but also life of the whole nation or even country: «»..."..the city or the country where the events take place may bethe hero. But the narrower your focus during the writing, the better»[Kushnir Y., 2015]. It is worth mentioning that each reporter uses his/her unique communicative strategy of work with characters of the reportage during the writing (direct work «in the field»), but it is necessary to detail two main points that are the most important for journalist's work, the quality,interestingness and text depth depend on.

\section{Reporter is a perfect interviewer}

The basis of the reporters' work is communication with their characters, journalists take interview being on the location where the eventor story take place. The first task the journalist has while working with a character is to convince the person of the importance of the story. "The journalist's business is to convince the person that it is worth talking» [Maletich N., 2012].

When the person is already «ready» to communicate, the journalist can interview. For the most part, reporters avoid unnecessary officialism, and ask the hero in light of the dynamics of communication development. Here everything is important: from the heroe's mood to the quality of the place for conversation. "A good reporter should be an anthropologist, since this science makes it possible to study a person in all spheres» [Tkachyshyn P., 2016].

Anattentive reporter avoids cliches in questions and prepares for a meeting with a hero. Putting correct, accurate, atmospheric questions, and also revealing the character - that's the main task for a reporter. Mostly during the conversation, journalists use open types of questions, trying tocarry on a conversation in such a way as to «take out» the 
character from the comfort zone. Each reporter takes notice of individual circumstances of the conversation, using four well-known journalistic techniques:

- conducting a conversation from default questions to specific ones;

- starting a conversation immediately from the very core of a subject;

- alternating questions from general to specific and spicy ones;

- conducting a conversation «smoothly» and then, unexpectedly for a person, asking a sharp question.

Polish reporters, working on social themes, advise to adhere to journalistic ethics and reword painful questions. Mariusz Szchigel and Wojciech Tohman emphasize that "the woman raped in Bosnia can not be asked to describe the rapist», "You do not have to ask the mother whose children were killed in the war about their birthday. But you can and must ask about everything else: their character and appearance, the things they loved and the way they studied. Dead children should be almost present between the reporter and the mother who mourns them. You have to refresh her memory. You need to talk as if they were there. And then the mother will talk about them with a kind of consolation» [Szczygieł M., Tochman W.,2011].

The same thing is to be applied to a press card, the reporters try to «blend into» the environment, without deceiving their hero, but however, without detracting him/her: «Reportage needs the truth, and it can change, if people find out that you are a journalist, sincethey may not tell you the things they will tell their friends and neighbors. There is no need to scare people with a press card»[Kovalenko O., Golovko K., 2014].

\section{Life from within or «live-in» method}

For a better understanding of the atmosphere and heroes of the text, Polish reporters are often present at the scene of the reportage using the well-known «live-in» reporting method or life from within. The method means visiting and staying in the center of reportage: the reporter goes straight to his/her heroes and lives with them for several days, observes their life and behavior, shows their real daily life. This method is an effective instrument of a well-grounded perception of the phenomenon, all the more, it is one of the methods of gathering information of «new journalism», the branch of which is Polish literature of fact. The «live-in» method provides an opportunity for deep observation and opens up prospects for journalistic observations. More often, Polish reporters in the texts live the same life as their heroes, or try to "get into" the life of the characters as much as possible.

For example, Jacek Hugo-Bader bought and upgraded «UAZik» (the vehicle manufactured at the Ulianovsk car factory) for his trips around Russia in order not to stand out in a crowd. "On the collective farm «llyich's Dream» on my «Audi Q7» I would look like an alien» [Hugo-Bader J., 2012,p.8]. He calls his communicative strategy «the method of a lost dog", the highest possible blending into the real life of the heroes. Or the example of Pavel Reshka, who at the time of the Revolution of Dignity in Ukraine lived in Pozniaky in Kiev to understand where the Maidan ends and routine life begins. Examine an event or astory from the other side, and not observe it from the top. «When you go to a store to buy something for breakfast, you talk there with a lady behind the counter, you get into the true life of the city and the country. In such a case you are an ordinary person and not a journalist» [Kovalenko O., Golovko K., 2014].

It is extremely important for the author to see what is happening, to hear the dialogues, to observe the gestures and mimicry of the characters, to feel the environmenton himself/herself , that is why the key feature of working with the heroes is to use their "live» language, dialogues in the text. Polish reporters try to present dialogues as what they are in a real life using the words used by their heroes. Truly and without adaptation. Sometimes for the authenticity of the situation a reporter uses words that reflect the environment in which an event occurs. 
All these things help a reader to move into the situation of a reportage, to feel the character, and even to remember its peculiarities. Mariusz Szczygiel emphasizes the use of the "people's» language in the reportage: «I often use interesting facts and expressions, heard from people, in my reportages. You won't invent it by yourself, so just take them and write them down. Then you will definitely use them in the text» [Salo I., 2013].

For example Witold Szablowski, in his reportage «Shipwreck», cites Mahmut - the hero of this reportage, who speaks colloquial language with the elements of obscenities, the reporter does this in order to convey the atmosphere and complexity of the situation, since his character shouts these words to his drug-addicted friend: «You get stoned! Holy crap! Again you get stoned!» - shouts Mahmut»[Szablowski W., 2012, p.179]. Through the use of the dialogs represented in such authentic form, the text «is saturated with» real emotions, the atmosphere of the situation in which the heroes live.

\section{Conclusions}

So, one of the key features of Polish reportage is the presence of unique, documentary, bold heroes in the texts, which illustrate the event, story or topic chosen by a journalist in the best way.

1. The main task for a reporter at the scene where the reportage takes place is to find proper characters and convince them of the importance of their story. Mostly, Polish reporters narrate about ordinary («epic») people (alive or dead ones as in the case ofW. Tochman's reports), with unusual, metaphorical stories. More rarely, journalists make reportages about political, cultural, and public personalities, because they have their own image created in the media space. Sometimes journalists themselves become the heroes of the reporting, as in the example with the married couple, which reproduced the way of Polish life in the 80 s of the twentieth century.

2. Often one reportage text combines several heroes at once for a better illustration of the theme. However, the central character still prevails with his/her «presence» in the text. For the most part, journalists unite reportages into cycles, blocks or publish books. Creating an effect when one story smoothly flows into another, they interchange characters in a random order, experimenting with the structure of texts. That is why Polish literature of fact so often appears in the book size.

3. During the direct work with a character, journalists use individual communicative strategies. First of all, a reporter must have proficient skills in interviewing. The journalists of the literature of fact work with the heroes of reports, adhering to the journalistic standards and the code of ethics, they consider the traditions and basics of Polish reportage school, where the story of the character is the core of the text.

4. In order to write a text in the best way Polish reporters use the method of «new journalism» - «live-in» or «life from withwin or their exceptional methods (Jacek Hugo-Bader "the method of the lost dog»), due to which they are staying in a real life of a character, blend into the environment of reporting, communicate and live with a character in one space. It helps a reporter to represent the "live» atmosphere of reportage, details and, of course, dialogues both between characters and the reporter, which makes the text unique and close to a reader.

\section{REFERENCES}

ABIS T.,(2013), «Izabela MeyzaTime Machine»,[online:September 17, 2013], available at: https://varianty.lviv.ua/14237-mashyna-chasu-izabely-.

AGNES Y., (2013), Journalist's Handbook: Let's write for newspapers, Kyiv,Publishing House "Kyiv-Mohyla Academy", vol. 544

BABENKO V., (2013), Narrative text in the news format, [online], available at: http://er.ucu.edu.ua/handle/1/711 
BALEY L. (2012),«Facts about Polish literature of fact» [online:April 9, 2012],available at: http://litakcent. com/2012/04/09/fakty-polskoji-literatury-faktu/

BALEY L.,(2012), A journey through the depths of souls: the author of «White Fever» on the specificfeatures of the post-Soviet space, [online:May 8, 2012],available athttp://tyzhden.ua/Culture/43125?attempt=1.

BALEY L., (2013), What should the perfect Ukrainian reportage look like?, [online:October 23, 2013], available at:http://litakcent.com/2013/10/23/jakym-maje-buty-idealnyj-ukrajinskyj-reportazh/

BARTOSZ M., (2010),Małgorzata Szejnert, [online: October, 2010],available at:https://culture.pl/ru/artist/malgozhata-sheynert

BERNACKI M., PAWLUS M. ,(1999), «Słownik gatunków literackich»,Park, vol. 611.

BOOK INSTITUTE POLAND.,available at:http://instytutksiazki.pl/literatura,8,indeks-autorow,26,wojciech-tochman,215.html?filter=T.

HUGO-BADER J., (2012), «White Fever: A Journey to the Frozen Heart of Siberia», Kyiv,Tempora, vol.338.

KNYAZEVICH 0.,(2011), Mariusz Szczygief - Reportage:the story that has actually took place and needsunderstanding, [online:December 11, 2011],available at: https://ucu.edu.ua/news/mariush-schyhel-reportazh-istoriya-yaka-dijsno-vidbulasya-i-potrebuje-osmyslennya-zik/

KOSTOVSKAYA A., (2016), Witold Shablovsky: I want"Righteous Traitors. Neighbors from Volyn "to become a bridge between the Poles and the Ukrainians, [online: December 16, 2016],available at:http://archive.chytomo. com/interview/vitold-shablovskij-xochu-shhob-pravedni-zradniki-susidi-z-volini-stala-mostom-mizh-polyakami-j-ukraiincyami

KOVALENKO 0., GOLOVKO K., (2014), Reporting rules by Pawel Reszka: "In front of Putin's apartment I saw Putin's Russia"», [online:October 28, 2014],available at:

https://ms.detector.media/mediaprosvita/master_clas/pravila_reportazhu_pavela_reshki_navproti_kvartiri_ putina_ya_pobachiv_putinsku_rosiyu/

KUSHNIR Y., (2015),Igor MiecikReporting Rules: "You will not be able to think out better than God has done"[online:November 2, 2015], available at:

http://ms.detector.media/mediaprosvita/master_clas/pravila_reportazhu_iora_mechika_vi_ne_zmozhete_vigadati_krasche_nizh_vigadav_bog/

MALETICH N.,(2013), Izabela Meyza: I do not believe in the fact that life "will be transferred" on Facebook, [online:October 10, 2013],available at:http://litakcent.com/2013/10/15/izabela-mejza-ne-virju-v-te-scho-zhyttja-perenesetsja-na-facebook/

MALETICH N., (2012), Jacek Hugo-Bader: There can be no better material for a journalist than a decay of a state, [online:April 1, 2012],available at:https://zaxid.net/yatsek_guobader_dlya_zhurnalista_ne_mozhe_buti_ krashhogo_materialu_nizh_zanepad_derzhavi_n1251576

SALO I.,(2013), Reporting makes it possible for a person to look into the windows of neighbors - Mariusz Szchigel, [online:April 8, 2013],available at:http://journalism.ucu.edu.ua/program-highlights/450/.

SHCHEGLOVA J.,(2012), Report as a translation from reality, [online:March 22, 2012], available at:https://zik. ua/news/2012/03/22/reportazh_yak_pereklad_z_realnosti_340279

SZABLOWSKI W., (2012), «The Assassin from Apricot City»,Kyiv,Tempora,vol .257

SZCZYGIEt M., TOCHMAN W.,(2011) A Reportage - a story about the things that actually happened, [December 27, 2011],available at:http://osvita.mediasapiens.ua/material/4200〉

TKACHYSHYN P. (2016),ReporterWitold Szabłowski: Poland is tired of learning freedom, it has now reared ontoits hind legs and began to dance, [online:October 1, 2016],available at:

http://ms.detector.media/mediaprosvita/master_clas/reportazhist_vitold_shablovskiy_polscha_vtomilas_vid_ navchannya_svobodi_vona_zaraz_stala_na_zadni_lapi_y_pochala_tantsyuvati/ 